\title{
Deep borehole disposal grouts - are inorganic retarders appropriate?
}

\section{Nicholas C. Collier}

Postdoctoral Research Associate, Deep Borehole Disposal Research Group, Immobilisation Science Laboratory, Department of Materials Science \& Engineering, The University of Sheffield, Sheffield, UK (corresponding author: nick.collier@sheffield.ac.uk)

\section{Sukanya H. Pawar}

MSc Student, Deep Borehole Disposal Research Group, Immobilisation Science Laboratory, Department of Materials Science \& Engineering, The University of Sheffield, Sheffield, UK

\section{Neil B. Milestone}

Distinguished Research Fellow, Callaghan Innovation, Lower Hutt, New Zealand

Karl P. Travis

Reader, Deep Borehole Disposal Research Group, Immobilisation Science Laboratory, Department of Materials Science \& Engineering, The University of Sheffield, Sheffield, UK

Cementitious grouts are being developed for use as sealing and support matrices (SSMs) in deep borehole disposal (DBD) of high-level radioactive waste. These SSMs will seal the waste containers within a disposal zone and provide physical support during package placement. The ambient temperature and pressure will be $80-130^{\circ} \mathrm{C}$ and $30-50 \mathrm{MPa}$, respectively, depending on depth and local geological conditions. This will accelerate grout thickening, so retardation is required to facilitate slurry placement. Certain inorganic materials suppress cement hydration and retard thickening under ambient conditions. However, their retardation characteristics are unknown at elevated temperature and pressure. Inorganic compounds of borate, phosphate, tin and zinc were investigated as retarders, and a summary of the work is provided in this paper. All retarders were found to delay thickening, with only borate providing sufficient retardation, but only at $90^{\circ} \mathrm{C}\left(0.75 \%\right.$ addition); retardation was nearly sufficient at $120^{\circ} \mathrm{C}(1 \%$ addition). The effect of all the retarders on wet paste properties was not consistent but, generally, plastic viscosity and yield stress peaked at specific addition levels. None of the retarders influenced phase composition, and each retarding ion was evenly distributed throughout the hardened microstructure. The results of this study led to the conclusion that no inorganic retarder is appropriate for use across the whole DBD temperature range.

\section{Background}

The disposal of high- and intermediate-level radioactive waste in the UK will be by co-disposal in a mined repository a few hundred metres deep known as a geological disposal facility (GDF). Deep borehole disposal (DBD) provides a potentially superior alternative to the comparatively shallow GDF concept for high-level waste, including spent fuel (Arnold et al., 2013; Beswick et al., 2014; Chapman and Gibb, 2003; Gibb, 2010a). DBD is based on sealing individual waste packages within a disposal zone in the lower $1-2 \mathrm{~km}$ of a borehole drilled up to $5 \mathrm{~km}$ deep (Beswick et al., 2014). This creates significant advantages over shallower disposal, with features such as increased safety, lower cost and ease of implementation (Gibb, 2010b). The DBD Research Group at The University of Sheffield is developing materials to provide sealing in the disposal zone. These materials are termed sealing and support matrices (SSMs) (Gibb et al., 2008) and their primary functions are $(a)$ to seal individual waste packages within the disposal zone and $(b)$ to provide a barrier to the ingress of saline groundwater to restrict container corrosion. The SSMs will also provide mechanical support to the waste packages to prevent buckling and, in the event of possible container failure during disposal zone filling, will provide an added seal/barrier against any radionuclides leaching into the borehole fluid. The temperature in the borehole will guide SSM selection and a cementitious grout would be used in lowtemperature situations.
BS EN ISO/API class G oil well cements (BS EN ISO 10426-1 (BSI, 2009)) are used as grouts in hydrocarbon and geothermal energy wells to secure the steel casing to the formation. These grouts also seal and separate the different fluid chemistries and rock formations through which the borehole passes (Nelson and Guillot, 2006; Taylor, 1997). Cementing operations performed in deep wells are challenging because the elevated temperature and pressure affects setting. These high-temperature and high-pressure conditions are due to the

(a) ambient temperature at the depths being considered for $\mathrm{DBD}$, where a range of $80-130^{\circ} \mathrm{C}$ would be typical (Best, 2003)

(b) radioactive decay heat from the waste packages

(c) local ambient pressure caused by the head of the borehole fluids (30-50 MPa).

Deploying DBD grouts at these elevated temperatures and pressures will be difficult. A DBD grout should be placed either coincidental with, or within a few hours of, package placement, so the influence of radioactive decay heat will be negligible. Both elevated temperature and pressure accelerate cement hydration reactions, reducing the time for the grout to thicken and set (Bensted, 2008; Collier et al., 2017a; Jupe et al., 2008; Nelson and Guillot, 2006; Scherer et al., 2010; Shariar and Nehdi, 2014; Taylor, 1997; Zhang et al., 2010), with temperature having greatest influence (Jupe et al., 2008; 
Nelson and Guillot, 2006; Scherer et al., 2010). Temperature also has a greater effect on the main cement hydrate phases formed (Collier et al., 2017a; Nelson and Guillot, 2006; Taylor, 1997) along with the calcium/silicon ratio. The limit of pumpability in well cementing grouts is considered to be the maximum consistency at which a grout can be pumped, and is reported to be $70 \mathrm{Bc}$ (Bearden units) (Nelson and Guillot, 2006). In this study, the limit of pumpability was taken as the maximum consistency at which a DBD grout can be pumped and at which it will flow around a waste package in a borehole. Drilling engineers are confident that DBD grouts could be delivered to the disposal zone in approximately $4 \mathrm{~h}$ (Beswick et al., 2014) (although shorter times may be possible), so this was taken as the minimum time required to maintain grout consistency at $\leq 70 \mathrm{Bc}$.

Organic retarders can delay grout thickening sufficiently for use in DBD (Collier et al., 2015a, 2015b, 2016). However, organics may complex radionuclides and adversely influence solubility, so their use in both radioactive waste immobilisation and in mined repositories is discouraged. This influence is less important in DBD because $(a)$ any radionuclide releases are only likely many years after borehole sealing and the geological barrier re-established and $(b)$ the elevated temperature and pressure and high $\mathrm{pH}$ of the cement grout will quickly decompose organic compounds (Collier et al., 2017a; Glasser, 1992, 1993). However, to address concerns about any possible impact of organic compounds, inorganic retarders are being investigated.

The retardation of cement hydration using organic materials is well reported (Wilding et al., 1984; Young, 1972). Far less information about the use of inorganic compounds exists; the majority of work has focused on lead $\left(\mathrm{Pb}^{2+}\right)$, tin $\left(\mathrm{Sn}^{2+}\right.$ and $\left.\mathrm{Sn}^{4+}\right)$, zinc $\left(\mathrm{Zn}^{2+}\right)$, borate $\left(\mathrm{BO}_{3}{ }^{3-}\right)$ and phosphate $\left(\mathrm{PO}_{4}{ }^{3-}\right)$ (Bénard et al., 2005, 2008; Ltifi et al., 2011; Ma and Brown, 1994; Odler, 2004; Taylor, 1997). All of these studies were performed under ambient conditions, making it difficult to assess applicability to the high-temperature and high-pressure conditions in DBD. Depending upon compound concentration and type, phosphate can retard for up to several days (Bénard et al., 2005, 2008; Cau-dit-Coumes and Courtois, 2003; Lieber, 1974; Ltifi et al., 2011; Ma and Brown, 1994), which could be due to the adsorption of phosphate ions to the surface of the cement, reducing or inhibiting dissolution (Bénard et al., 2005; Lieber, 1974). Other researches have reported that phosphate retardation occurs up to a certain concentration $(25 \mathrm{~g} / \mathrm{l}$ of grout mix water, equivalent to $\sim 1 \cdot 25 \%$ ), above which there is acceleration (Bénard et al., 2005; Cau-dit-Coumes and Courtois, 2003; Ma and Brown, 1994). Previous work by the authors using phosphate (Collier et al., 2017b) corroborates this, with a change in consistency and viscosity at addition levels around 1-2\% noted. Borate can cause retardation (Atabek et al., 1992; Demirbas and Karslioglu, 1995; Ramachandran and Lowery, 1998) and occurs because the ions react with the cement to form calcium borate phases that then adsorb onto the cement and precipitate slightly soluble layers (Bell and Coveney, 1998; Bensted et al., 1991; Csetenyi and Glasser, 1995). Zinc or tin retards early hydration (Hill and Sharp, 2005), resulting in the formation of either a calcium zincate phase (CaZn $\left.(\mathrm{OH})_{6} \cdot 2 \mathrm{H}_{2} \mathrm{O}\right)$ (Cocke and Mollah, 1993; Hill, 1999; Ivey et al., 1990; Odler, 2004; Thomas et al., 1981) or an analogous tin phase $\left(\mathrm{CaSn}(\mathrm{OH})_{6}\right)$ (Bonhoure et al., 2003; Gao and Song, 2013; Hill, 1999; Hill and Sharp, 2003a; Lothenbach et al., 2000). Retardation by tin depends on the type and amount of salt added, suggesting that different retardation mechanisms may be occurring with different compounds (tin(II) chloride $\left(\mathrm{SnCl}_{2}\right)$ is reported to act only as a retarder, whereas tin(IV) chloride $\left(\mathrm{SnCl}_{4}\right)$ is reported to retard up to addition levels of $\sim 1 \%$, after which it acts as an accelerator; this could be due to the heat generated during early hydration) (Hill and Sharp, 2003b). The formation of calcium zincate retards by the precipitation of an amorphous layer of zinc hydroxide on the cement particles, which then reacts with calcium hydroxide to form calcium zincate (Arliguie et al., 1982; Cocke and Mollah, 1993; Thomas et al., 1981). Similarly, other workers have reported that zinc retardation is caused by the deposition of an amorphous gel on cement particles (Ivey et al., 1990; Thomas et al., 1981). This process of coating cement particles suggests that the mechanism of retardation using these inorganic additives is different to when using organic materials, which is largely based on calcium complexation (Taylor, 1997).

Inorganic compounds of borate and phosphate retard grout thickening, and appear to have no influence on the composition and microstructure of hydrothermally cured cementitious grouts (based on class $\mathrm{G}$ oil well cement) being developed for use as SSMs. However, the resultant delays were insufficient for use across the temperature range likely to be experienced in DBD. The work reported here assessed the use of inorganic compounds of tin $(\mathrm{Sn})$ and zinc $(\mathrm{Zn})$ to retard hydration in the same DBD grouts, and further assessed the overall applicability of all the inorganic compounds investigated. The work focused on the thickening time and rheological properties of the wet pastes and the composition and microstructural characteristics of hardened pastes, when used at elevated temperatures and pressures. The applicability to other uses of cementitious grouts in DBD, as well as in hydrocarbon and geothermal energy wells, was also assessed.

\section{Experimental details}

\section{Materials and sample preparation}

Dyckerhoff American Petroleum Institute (API) class G HSR oil well cement (BS EN ISO 10426-1 (BSI, 2009) and API Spec 10A (API, 2010)) partially replaced with silica flour was used to make the grout. The cement was supplied by Cebo UK Ltd and was manufactured to BS EN ISO 10426-1/API Spec 10A. The silica flour was supplied by Minerals Marketing Ltd (A50 silica flour). The compositions of both 
Table 1. Oxide composition of class $G$ cement and silica flour

\begin{tabular}{|c|c|c|}
\hline & Class G cement & Silica flour \\
\hline Silicon dioxide $\left(\mathrm{SiO}_{2}\right)$ : wt\% & $21 \cdot 8$ & $99 \cdot 7$ \\
\hline Aluminium oxide $\left(\mathrm{Al}_{2} \mathrm{O}_{3}\right)$ : wt\% & $4 \cdot 2$ & $0 \cdot 10$ \\
\hline Ferric oxide $\left(\mathrm{Fe}_{2} \mathrm{O}_{3}\right)$ : wt\% & $5 \cdot 3$ & 0.03 \\
\hline Magnesium oxide (MgO): wt\% & 0.6 & 0.004 \\
\hline Calcium oxide $(\mathrm{CaO})$ : $\mathrm{wt} \%$ & $64 \cdot 1$ & 0.006 \\
\hline Sulfur trioxide $\left(\mathrm{SO}_{3}\right)$ : wt $\%$ & $2 \cdot 7$ & - \\
\hline Loss on ignition: wt\% & $1 \cdot 2$ & $0 \cdot 10$ \\
\hline Total: wt \% & 99.9 & 99.9 \\
\hline
\end{tabular}

Table 2. Cement phase composition of class G cement

$\begin{array}{lc}\text { Cement phase }^{a} & \text { Phase content: wt\% } \\ \mathrm{C}_{3} \mathrm{~S} & 54 \cdot 4 \\ \beta-\mathrm{C}_{2} \mathrm{~S} & 22 \cdot 3 \\ \mathrm{C}_{3} \mathrm{~A} & 2 \cdot 0 \\ \mathrm{C}_{4} \mathrm{AF} & 16 \cdot 4\end{array}$

${ }^{a}$ Calculated from ASTM C150/C150M (ASTM, 2016) and using cement oxide nomenclature $\mathrm{C}=\mathrm{CaO}, \mathrm{S}=\mathrm{SiO}_{2}, \mathrm{H}=\mathrm{H}_{2} \mathrm{O}, \mathrm{A}=\mathrm{Al}_{2} \mathrm{O}_{3}$ and $\mathrm{F}=\mathrm{Fe}_{2} \mathrm{O}_{3}$

powders are detailed in Tables 1 and 2. To enable the mixed grout to flow through water without dispersion of solid particles, an underwater additive (UCS Pak) supplied by Sika Ltd was used, which is reported to contain silica and organic compounds.

Two inorganic compounds were investigated as retarders of grout thickening - tin chloride $\left(\mathrm{SnCl}_{2}\right)$ and zinc nitrate (zinc nitrate hexahydrate, $\left.\mathrm{Zn}\left(\mathrm{NO}_{3}\right)_{2} \cdot 6 \mathrm{H}_{2} \mathrm{O}\right)$ - and these were compared with the compounds investigated in earlier work (Collier et al., 2017b), sodium phosphate (di-sodium hydrogen phosphate, $\mathrm{Na}_{2} \mathrm{HPO}_{4} .7 \mathrm{H}_{2} \mathrm{O}$ ) and sodium borate (di-sodium tetraborate pentahydrate, $\mathrm{Na}_{2} \mathrm{~B}_{4} \mathrm{O}_{7} .5 \mathrm{H}_{2} \mathrm{O}$ ). All the retarders were laboratory-grade chemicals, with the tin and zinc compounds supplied by Fisher Scientific and the phosphate and borate compounds by Sigma Aldrich. Water was used to mix the grouts, which had a density after mixing (excluding any retarder) of $1.892 \mathrm{~kg} / \mathrm{m}^{3}$. Grout mixing was performed to BS EN ISO 10426-1 (BSI, 2009) at ambient temperature $\left(\sim 22^{\circ} \mathrm{C}\right)$ and pressure $(\sim 0 \cdot 1 \mathrm{MPa})$. All inorganic compounds were dissolved in the water before the addition of the dry powders.

\section{Sample analysis}

Grout consistency was measured in an API-certified consistometer using a linear heating/pressurising regime, increasing from ambient to either 90 or $120^{\circ} \mathrm{C}$ and $50 \mathrm{MPa}$ over $4 \mathrm{~h}$ to simulate the conditions during pumping/lowering down a borehole. After the $4 \mathrm{~h}$ heating period, temperature and pressure were maintained until consistency exceeded the upper limit of detection. The time to reach the minimum consistency and the time to reach $70 \mathrm{Bc}$ (at which the grout will no longer flow around waste packages) were recorded. Initial grout consistency should not exceed $70 \mathrm{Bc}$ because this would mean it could not be pumped during deployment. For each grout where $70 \mathrm{Bc}$ was reached after $4 \mathrm{~h}$, final set by $24 \mathrm{~h}$ was checked using manual Vicat testing equipment (ASTM C191-13 (ASTM, 2013)). The times at which the main cement hydration reactions occurred, and the magnitude of the heat evolved, were recorded using a TAM Air isothermal calorimeter set at $85^{\circ} \mathrm{C}$. Viscosity and yield stress data were obtained using a HAAKE VT550 viscometer operating at ambient temperature and pressure.

The phase compositions of the hardened grouts were determined by casting freshly mixed samples containing $2 \%$ (by weight of cement) sodium phosphate, sodium borate, tin chloride or zinc nitrate, and hydrothermally curing them under water in sealed containers at $120^{\circ} \mathrm{C}$ for 7,14 and $28 \mathrm{~d}$. Retarder-free control samples were also produced. After each time interval, hydration was arrested using a solvent replacement technique (Collier et al., 2008) and the composition was determined by X-ray diffraction (XRD) and thermogravimetric analysis/derivative thermogravimetric analysis (TGA/DTG). A Bruker D2 Phaser X-ray diffractometer was operated between 5 and $90^{\circ} 2 \theta$ at $2^{\circ} \theta / \mathrm{min}$, and a Perkin Elmer Pyris 1 thermogravimetric analyser was operated using a heating profile of $30-1000^{\circ} \mathrm{C}$ at $10^{\circ} \mathrm{C} / \mathrm{min}$ in flowing nitrogen. Microstructural morphology and elemental distribution within the $28 \mathrm{~d}$ samples was investigated using a Hitachi TM3030 scanning electron microscope (SEM) fitted with an energy dispersive spectrometer (EDX).

\section{Results}

Wet paste properties

Consistency plots of the grouts containing tin chloride tested to a target temperature of $120^{\circ} \mathrm{C}$ are shown in Figure 1 (the pressure graph is omitted for clarity) and consistency data from all the tests are summarised in Figure 2. To reiterate, this testing was used to ascertain which retarders could delay the time at which the consistency of the grouts reached $70 \mathrm{Bc}$ (the consistency at which grout would cease to flow around waste containers) to at least $4 \mathrm{~h}$ (the estimated package delivery time). For each grout, there was an initial increase in consistency during the first $10 \mathrm{~min}$ (where temperature increased from 20 to $25^{\circ} \mathrm{C}$ ). Apart from some instances of a slight consistency increase (as shown in Figure 1 between $\sim 0.5$ and $1 \mathrm{~h}$ ), consistency generally decreased with increasing time, temperature and pressure. At the end of testing, there was a rapid increase towards $100 \mathrm{Bc}$, the point at which the instrument stopped measuring.

Figure 2 shows the times at which minimum consistency was reached (the lowest time on each plot) and the time when consistency reached $70 \mathrm{Bc}$ (the highest time on each plot) when tested at 90 and $120^{\circ} \mathrm{C}$. The results for the borate and phosphate compounds are included for comparison (Collier et al., 


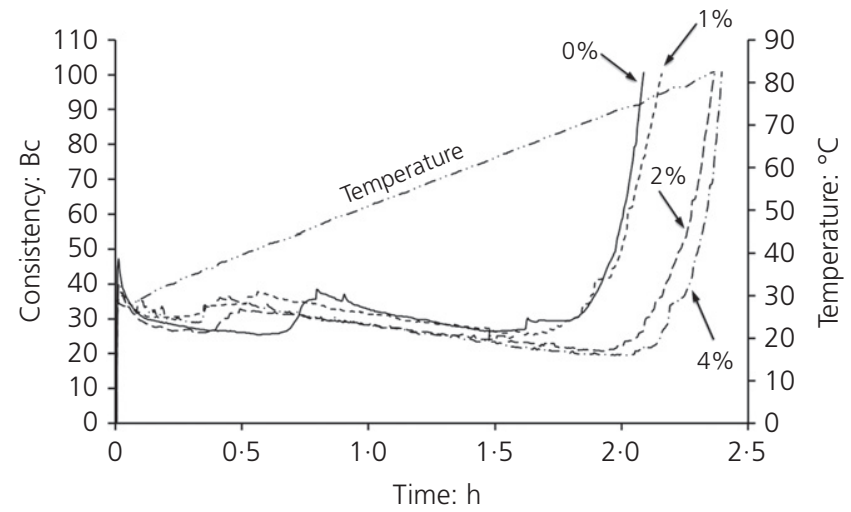

Figure 1. Consistency of grouts containing tin chloride $\left(120^{\circ} \mathrm{C}\right.$ and $50 \mathrm{MPa}$ ) 2017b). The tests focused on retardation at both testing temperatures, so an iterative approach was taken, meaning that not all tests were performed at each temperature. The control grout took less than $4 \mathrm{~h}$ to reach $70 \mathrm{Bc}$, confirming the need for retardation. The accelerating effect of a higher testing temperature can be readily seen by the shift in the graphical plots to earlier times for the control grout at 90 and $120^{\circ} \mathrm{C}$, and in the grouts containing $2 \cdot 0 \%$ or $4.0 \%$ tin chloride. The data show that only sodium borate provided sufficient delay in reaching $70 \mathrm{Bc}$, and only at $90^{\circ} \mathrm{C}$ (possible with additions of $0 \cdot 75,1 \cdot 0$ and $2.0 \%$ ). Adding $1.0 \%$ borate nearly retarded sufficiently at $120^{\circ} \mathrm{C}$, but increasing to $2 \cdot 0 \%$ meant that the grout was too viscous to be tested $(>100 \mathrm{Bc})$. All the other additives only provided slight retardation, particularly the zinc nitrate. Graphical plots of maximum initial consistency (Figure 3) show that, at both temperatures, the any addition of tin chloride or sodium phosphate had little influence on initial
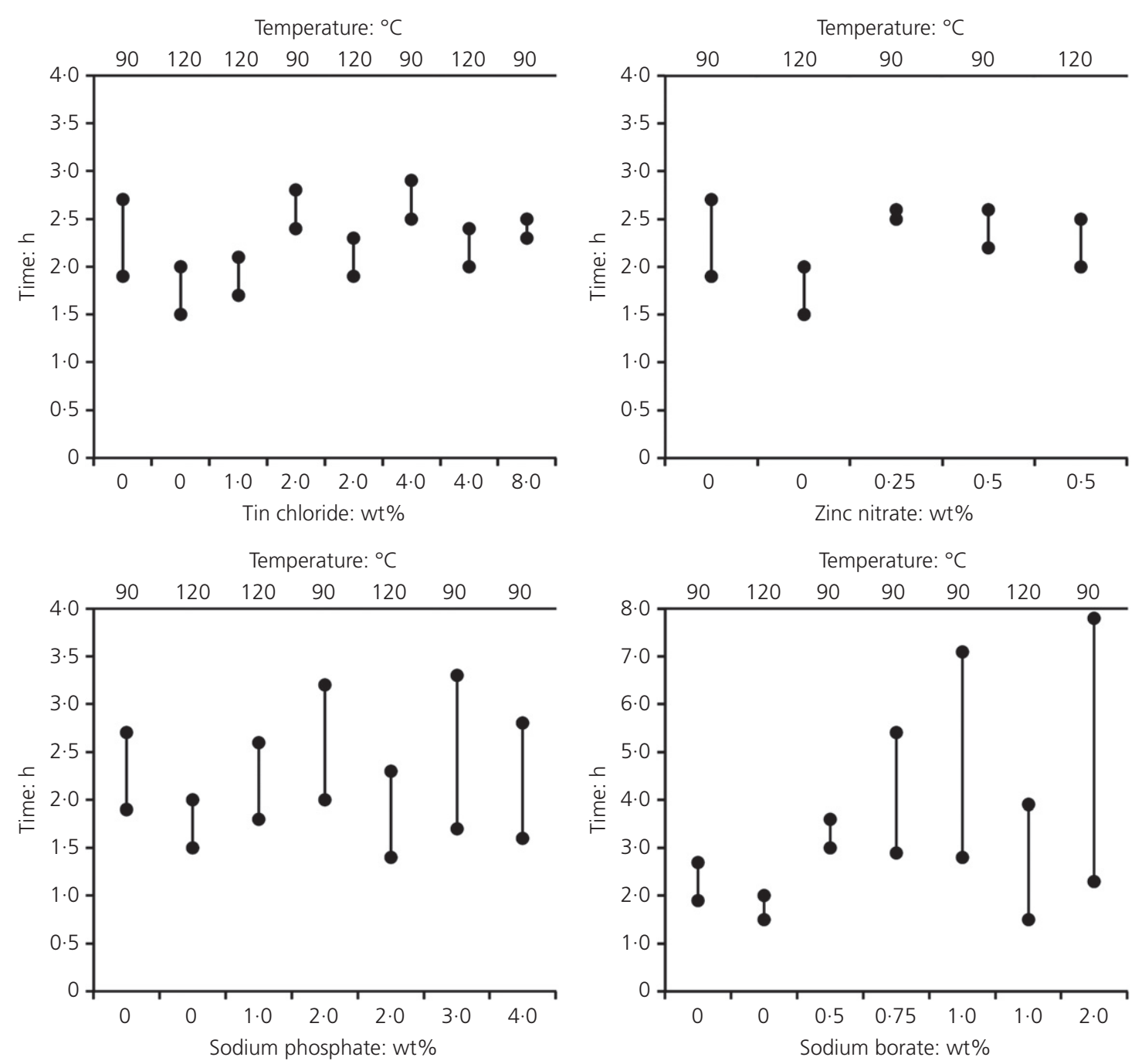

Figure 2. Summary of consistency times. The graphs show the times at which minimum consistency was reached (the lower time on each plot) and when the consistency reached $70 \mathrm{Bc}$ (the higher time on each plot), for each addition level. $0 \mathrm{~h}$ was the test start time 


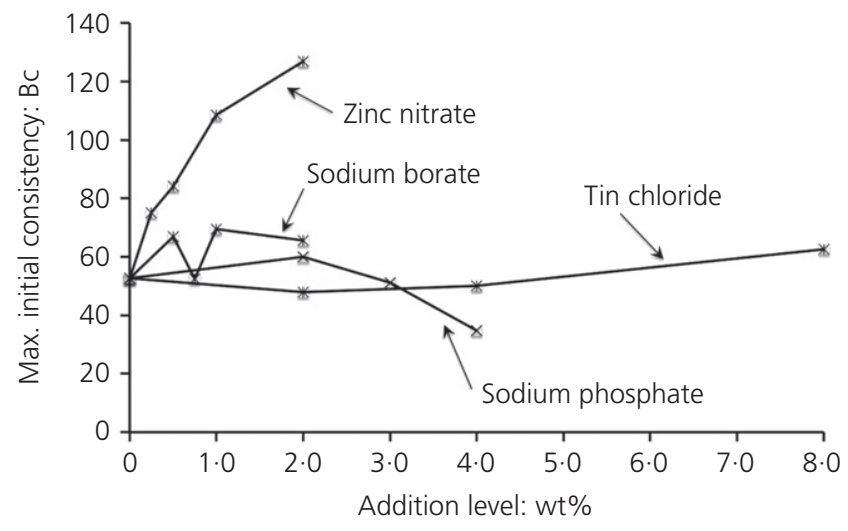

(a)

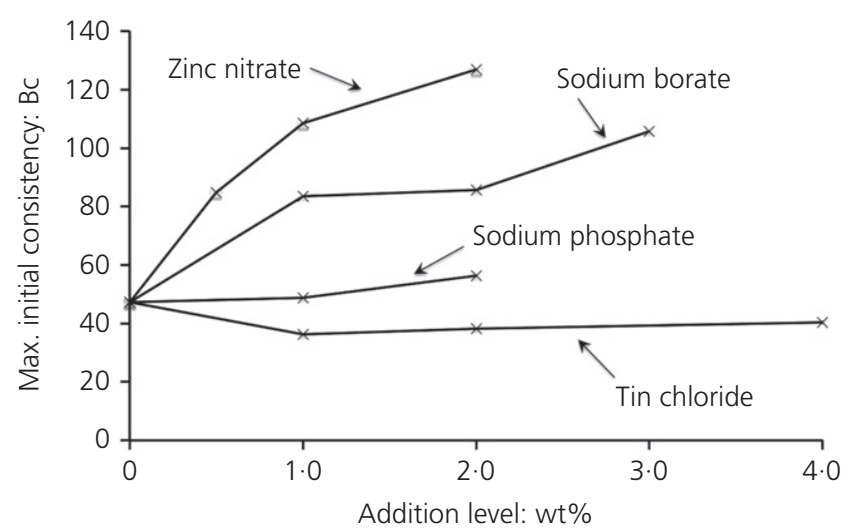

(b)

Figure 3. Maximum initial consistency at (a) $90^{\circ} \mathrm{C}$ and (b) $120^{\circ} \mathrm{C}$

consistency. However, adding either zinc nitrate or sodium borate caused the initial consistency to increase with addition level. This suggests that the latter two compounds had a greater influence on wet paste properties. All grouts achieved final set within $24 \mathrm{~h}$.

Stress-shear rate curves for the tin chloride and zinc nitrate grouts are shown in Figure 4. Data for the borate and phosphate grouts were published previously (Collier et al., 2017b) and, from discussions on that work, the experimental process was refined for the tin and zinc grouts. The data were plotted over the shear rate range $20-100 \mathrm{~s}^{-1}$, a linear fit to each dataset was applied over this range and then the line was extrapolated to intersect with the stress axis to determine the yield stress. The gradient of each linear fit line was recorded as the plastic viscosity. The yield stress and plastic viscosity for the tin and zinc grouts are listed in Table 3; compared with the control grout, both parameters for the tin grouts were less at each addition level, whereas the opposite was true for the zinc grouts. This suggests that tin chloride acts as a plasticiser whereas zinc nitrate acts as a thickening agent. Plastic viscosity and yield stress increased with increasing tin chloride addition levels to a maximum at $4 \cdot 0 \%$, after which a decrease in both

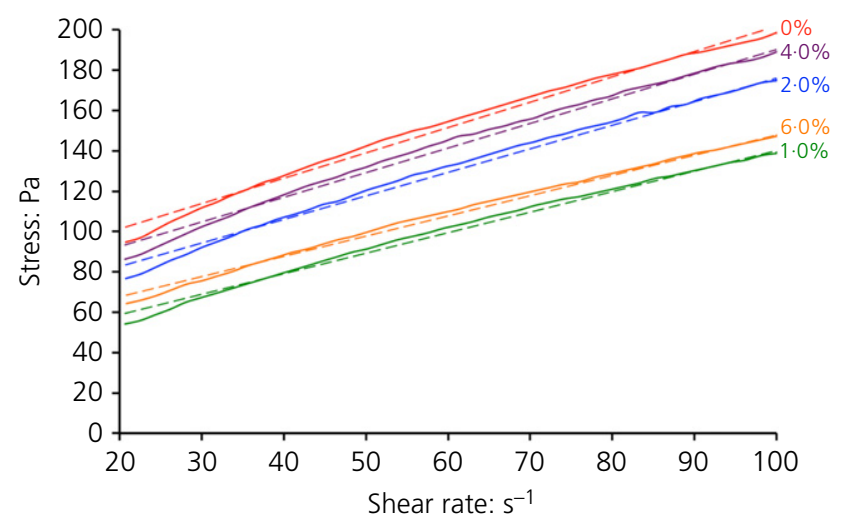

(a)

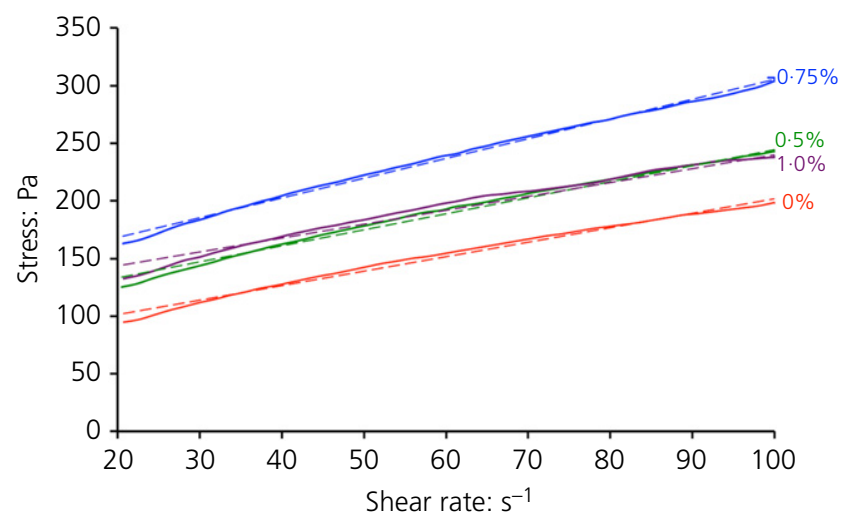

(b)

Figure 4. Viscometer results for grouts made with (a) tin chloride and (b) zinc nitrate. Dashed lines are linear fits to each set of data; the coefficients of determination $\left(R^{2}\right)$ varied between 0.986 and 0.998 across these fits

Table 3. Viscosity and yield stress of grouts containing tin chloride and zinc nitrate

\begin{tabular}{|lccc|} 
& $\begin{array}{c}\text { Addition } \\
\text { level: } \mathbf{w t} \%\end{array}$ & $\begin{array}{c}\text { Plastic } \\
\text { viscosity: Pa.s }\end{array}$ & $\begin{array}{c}\text { Yield } \\
\text { stress: Pa }\end{array}$ \\
\hline Control & 0.0 & 1.26 & 76.16 \\
Tin chloride & 1.0 & 1.02 & 38.36 \\
& 2.0 & 1.17 & 59.26 \\
& 4.0 & 1.22 & 68.12 \\
Zinc nitrate & 6.0 & 1.00 & 47.55 \\
& 0.50 & 1.39 & 105.38 \\
& 0.75 & 1.71 & 133.94 \\
& 1.00 & 1.20 & 119.52 \\
& & &
\end{tabular}

parameters was observed. The same trend was seen for the zinc nitrate up to a maximum at $0.75 \%$ addition. This shows that the effect of these retarders on wet paste properties is complex and is likely to be mostly of a chemical nature. Comparison with the borate and phosphate grouts is difficult because different testing methodologies were used (for the borate and phosphate grouts a single-point measurement was taken at a shear rate of $10 \mathrm{~s}^{-1}$, and this was outside the range of data assessed 
for the tin and zinc grouts). However, the trends of plastic viscosity and yield stress peaking as addition levels increased were observed in all the grouts, suggesting an optimum addition level.

The influence of the inorganic materials on the magnitude of the main exotherms generated during hydration, and the times at which they occurred, was studied using calorimetry (Figure 5). The results show a distinct reduction in the magnitude of the heat flow events and a retardation of the times at which they occur, as the quantity of either borate or zinc was increased $(13.4 \mathrm{~W} / \mathrm{kg}$ at $4.8 \mathrm{~h}, 9.0 \mathrm{~W} / \mathrm{kg}$ at $9.3 \mathrm{~h}$ and $8.4 \mathrm{~W} / \mathrm{kg}$ at $37 \cdot 1 \mathrm{~h}$ with borate additions of $0,1,2 \%$, respectively; $14.6 \mathrm{~W} / \mathrm{kg}$ at $4.5 \mathrm{~h}, 12.7 \mathrm{~W} / \mathrm{kg}$ at $5.6 \mathrm{~h}$ and $10.3 \mathrm{~W} / \mathrm{kg}$ at $7.2 \mathrm{~h}$ for zinc additions of $0,0.25$ and $0.5 \%$, respectively). The magnitude of the heat flow events in the tin grouts increased with addition level and the times at which they occurred reduced, suggesting that hydration was accelerated as addition levels were increased $(14.6 \mathrm{~W} / \mathrm{kg}$ at $4.5 \mathrm{~h}, 17.9 \mathrm{~W} / \mathrm{kg}$ at $1.7 \mathrm{~h}$ and $26.8 \mathrm{~W} / \mathrm{kg}$ at $1.9 \mathrm{~h}$ for $0,2.0$ and $4.0 \%$ tin additions, respectively). The phosphate grout behaved similarly to the tin grout, although the effects were less distinct $(13.4 \mathrm{~W} / \mathrm{kg}$ at $4.8 \mathrm{~h}$, $11.9 \mathrm{~W} / \mathrm{kg}$ at $4.7 \mathrm{~h}$ and $9.9 \mathrm{~W} / \mathrm{kg}$ at $3.8 \mathrm{~h}$ with $0,1.0$ and $2.0 \%$ phosphate additions, respectively). These data suggest that phosphate has little influence on initial cement hydration. Both the zinc and phosphate grouts showed a doublet in heat flow at 0.5
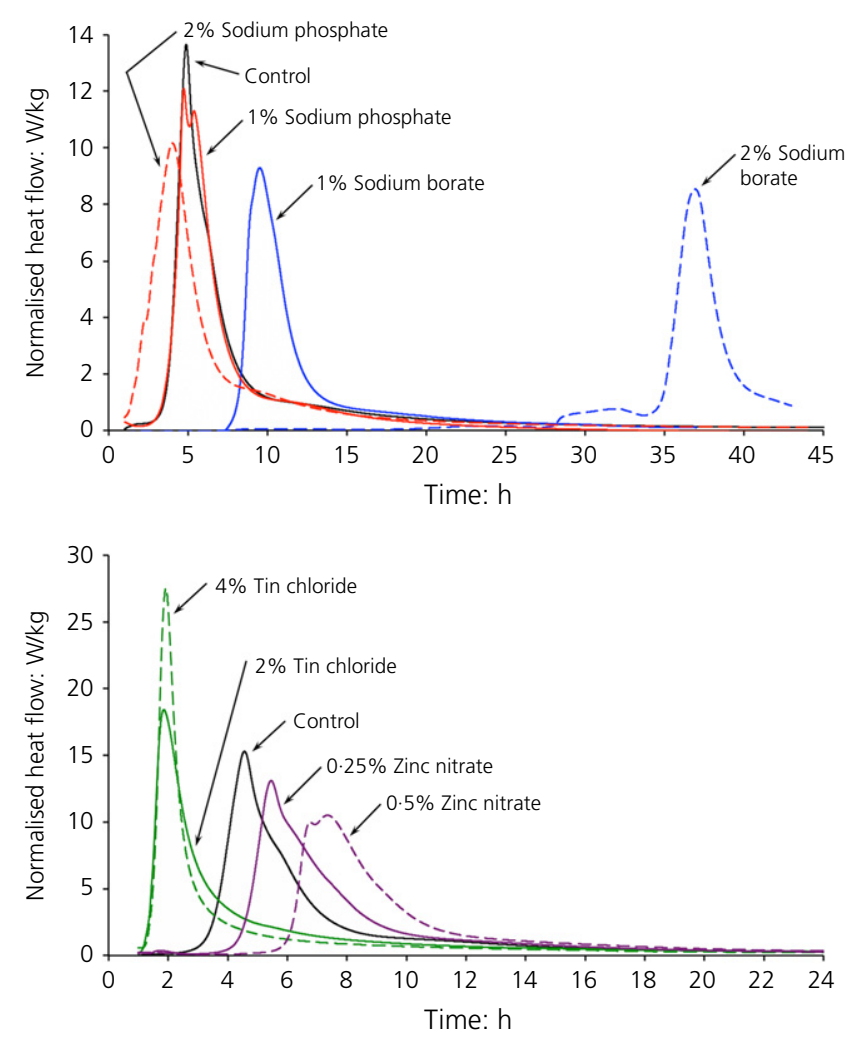

Figure 5. Summary of calorimetry results and $2 \cdot 0 \%$ additions, respectively, suggesting a complex influence on hydration.

\section{Hardened paste composition}

X-ray diffractograms of the tin and zinc grouts (Figure 6) show the development of crystalline phases with curing time. Quartz from the silica dominated all the results, making it difficult to identify minor phases and discern trends. However, the minor phases identified were $(a)$ the crystalline calcium silicate hydrate $(\mathrm{C}-\mathrm{S}-\mathrm{H})$ phases $\alpha-\mathrm{C}_{2} \mathrm{SH}\left(\mathrm{Ca}_{2}\left(\mathrm{SiO}_{4}\right) \mathrm{H}_{2} \mathrm{O}\right)$ and tobermorite- $\left.11 \AA\left(\mathrm{Ca}_{5} \mathrm{Si}_{6}(\mathrm{OH})_{18}\right)\right)$, $(b)$ portlandite $\left(\mathrm{Ca}(\mathrm{OH})_{2}\right)$ and $(c)$ brownmillerite $\left(\mathrm{Ca}_{2} \mathrm{FeAl}_{2} \mathrm{O}_{5}\right.$, an unhydrated relic from the cement). The intensities of the quartz reflections decreased with time as reaction occurred with the calcium phases present (Bensted, 2008; Nelson and Guillot, 2006; Taylor, 1997). Weak reflections for portlandite were detected (at 18.09 and $34.09^{\circ} 2 \theta$ ), the intensity of which decreased with time, suggesting a reaction with the quartz. The main reflections for tobermorite- $11 \AA$ were evident (at 7.83 and $28.95^{\circ} 2 \theta$ ), although their intensities were very low, making it difficult to confirm trends. Very weak reflections were identified for $\alpha-\mathrm{C}_{2} \mathrm{SH}$, and only in the $7 \mathrm{~d}$ control and zinc sample. Weak reflections for brownmillerite were identified in all samples at all ages, and had similar intensities, suggesting little if any hydration over $28 \mathrm{~d}$. These results were very similar to those for the borate and phosphate grouts, indicating that none of the inorganic compounds studied have a major influence on crystalline phase formation. However, as previously reported (Collier et al., 2017b), the borate and phosphate may slightly suppress the formation of crystalline $\mathrm{C}-\mathrm{S}-\mathrm{H}$ phases.

To study crystalline phase formation further, the intensity of the principal reflection for each of the main phases was compared to that of brownmillerite, selected as a reference because of its unreactivity at these temperatures (Bensted, 2008; Nelson and Guillot, 2006; Taylor, 1997) (Table 4). The trends in phase

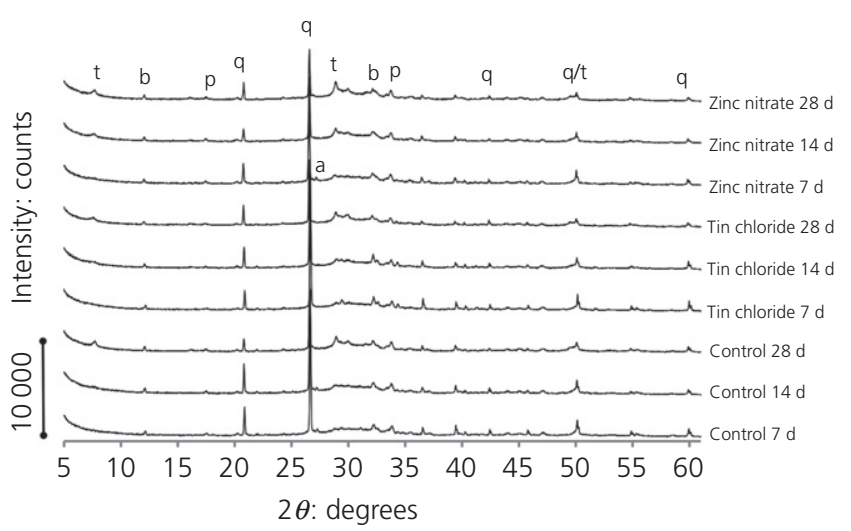

Figure 6. XRD diffractograms of tin chloride and zinc nitrate samples: q, quartz; $\mathrm{p}$, portlandite $\left(\mathrm{Ca}(\mathrm{OH})_{2}\right) ; \mathrm{a}_{1} \alpha-\mathrm{C}_{2} \mathrm{SH}\left(\mathrm{Ca}_{2}\left(\mathrm{SiO}_{4}\right)\right.$ $\left.\mathrm{H}_{2} \mathrm{O}\right)$; t tobermorite- $11 \AA\left(\mathrm{Ca}_{5} \mathrm{Si}_{6}(\mathrm{OH})_{18}\right) ; b$, brownmillerite $\left(\mathrm{Ca}_{2} \mathrm{FeAl}_{2} \mathrm{O}_{5}\right)$ 
Table 4. Intensity of the principal XRD reflection for the main phases present relative to that of brownmillerite

\begin{tabular}{|c|c|c|c|c|}
\hline \multirow[b]{2}{*}{ Sample } & \multicolumn{4}{|c|}{ Relative intensity of main XRD reflection ${ }^{a}$} \\
\hline & Quartz $^{b}$ & $\begin{array}{c}\text { Tobermorite- } \\
11 \AA^{c}\end{array}$ & $\begin{array}{c}\alpha- \\
\mathrm{C}_{2} \mathrm{SH}^{\mathrm{d}}\end{array}$ & Portlandite ${ }^{e}$ \\
\hline \multicolumn{5}{|c|}{ Control: d } \\
\hline 7 & $12 \cdot 79$ & 0.89 & 1.05 & $1 \cdot 28$ \\
\hline 14 & $8 \cdot 41$ & 1.01 & 0.91 & $1 \cdot 17$ \\
\hline 28 & $6 \cdot 36$ & $1 \cdot 23$ & 0.73 & $1 \cdot 16$ \\
\hline \multicolumn{5}{|c|}{ Phosphate: d } \\
\hline 7 & 9.69 & $0 \cdot 70$ & 0.64 & $1 \cdot 81$ \\
\hline 14 & $10 \cdot 87$ & 0.80 & 0.80 & 1.25 \\
\hline 28 & $7 \cdot 79$ & 0.98 & 0.66 & $1 \cdot 14$ \\
\hline \multicolumn{5}{|c|}{ Borate: $d$} \\
\hline 7 & $12 \cdot 05$ & 0.91 & $0 \cdot 80$ & $1 \cdot 17$ \\
\hline 14 & $9 \cdot 23$ & 0.92 & 0.83 & $1 \cdot 19$ \\
\hline 28 & 8.42 & 1.09 & 0.85 & $1 \cdot 13$ \\
\hline \multicolumn{5}{|l|}{ Tin: $d$} \\
\hline 7 & $12 \cdot 41$ & 0.97 & $0 \cdot 82$ & $1 \cdot 24$ \\
\hline 14 & $7 \cdot 59$ & 0.98 & 0.78 & $1 \cdot 20$ \\
\hline 28 & $5 \cdot 62$ & 0.99 & $0 \cdot 71$ & 1.05 \\
\hline \multicolumn{5}{|l|}{ Zinc: $d$} \\
\hline 7 & $7 \cdot 20$ & 0.98 & 1.02 & 1.23 \\
\hline 14 & $5 \cdot 61$ & 1.06 & $0 \cdot 75$ & $1 \cdot 17$ \\
\hline 28 & $4 \cdot 10$ & $1 \cdot 15$ & 0.67 & $1 \cdot 11$ \\
\hline
\end{tabular}

${ }^{a}$ Compared with the main reflection for brownmillerite at $33.719^{\circ} 2 \theta$ (PDF 71-0667). This was used as a reference because it is unreactive (Bensted, 2008; Nelson and Guillot, 2006; Taylor, 1997) and the intensity of the main reflection was very similar in each sample

${ }^{b}$ Quartz (PDF 77-1060); angle of principal reflection 26.628 $2 \theta$

${ }^{C}$ Tobermorite-11A (PDF 45-1480); angle of principal reflection $7 \cdot 831^{\circ} 2 \theta$

${ }^{\mathrm{d}} \alpha-\mathrm{C}_{2} \mathrm{SH}$ (PDF 81-1987); angle of principal reflection $27 \cdot 250^{\circ} 2 \theta$

e Portlandite (PDF 44-1481); angle of principal reflection $34.094^{\circ} 2 \theta$

formation for the control sample match other results in the literature: (a) quartz and portlandite content reduced with time, suggesting a reaction between both; $(b)$ there was a reduction in $\alpha-\mathrm{C}_{2} \mathrm{SH}$; $(c)$ there was an increase in tobermorite (Bensted, 2008; Nelson and Guillot, 2006). The grouts containing tin, zinc and borate displayed the same trends although, for the borate samples, there was a slight increase in $\alpha-\mathrm{C}_{2} \mathrm{SH}$ with time, and the quantity of quartz in the zinc samples was less than in all the other samples. The results for the phosphate samples were somewhat inconsistent; there was an increase in quartz from 7 to $14 \mathrm{~d}$ and the $\alpha-\mathrm{C}_{2} \mathrm{SH}$ content showed no progressive increase or decrease other than an initial peak. This suggests that the additives only slightly influenced crystalline phase formation and that, generally, the associated trends were similar to that of the control.

TGA/DTG was used to measure the mass loss within specific temperature ranges (known to be within which specific cement hydrate phases decompose (Collier, 2016)) (Table 5). The total mass loss from each sample increased with curing time (apart from the borate samples, probably due to an experimental anomaly) demonstrating ongoing hydration. All samples showed an increase in $\mathrm{C}-\mathrm{S}-\mathrm{H}$ with time, with the phosphate grout showing the greatest change. $\mathrm{C}-\mathrm{S}-\mathrm{H}$ phases are formed
Table 5. TGA/DTG mass loss data

\begin{tabular}{llll} 
& \multicolumn{3}{c}{ Mass loss: \% of sample } \\
\cline { 3 - 4 } Sample & Total C-S-H phases $^{\mathrm{a}}$ & Calcium hydroxide & \\
Control & Total $^{\mathrm{c}}$ \\
$7 \mathrm{~d}$ & & & \\
$14 \mathrm{~d}$ & 11.75 & 1.95 & 14.47 \\
$28 \mathrm{~d}$ & 11.90 & 1.97 & 14.73 \\
Sodium phosphate & 12.91 & 1.56 & 15.22 \\
$7 \mathrm{~d}$ & 10.58 & & \\
$14 \mathrm{~d}$ & 11.60 & 1.74 & 13.23 \\
$28 \mathrm{~d}$ & 13.45 & 1.87 & 14.42 \\
Sodium borate & & 1.53 & 15.71 \\
$7 \mathrm{~d}$ & 11.54 & & \\
$14 \mathrm{~d}$ & 12.24 & 2.04 & 14.51 \\
$28 \mathrm{~d}$ & 12.55 & 2.12 & 15.49 \\
Tin chloride & & 1.66 & 14.96 \\
$7 \mathrm{~d}$ & 11.86 & & \\
$14 \mathrm{~d}$ & 12.25 & 1.70 & 15.14 \\
$28 \mathrm{~d}$ & 12.82 & 1.69 & 15.15 \\
Zinc nitrate & & 1.80 & 15.79 \\
$7 \mathrm{~d}$ & 12.12 & & \\
$14 \mathrm{~d}$ & 12.40 & 1.89 & 15.03 \\
$28 \mathrm{~d}$ & 12.69 & 1.66 & 15.05 \\
& & 1.66 & 15.30 \\
\end{tabular}

${ }^{a}$ Temperature range $25-600^{\circ} \mathrm{C}$, excluding weight loss from calcium hydroxide ${ }^{\mathrm{b}}$ Temperature range $400-500^{\circ} \mathrm{C}$

${ }^{\mathrm{C}}$ Temperature range $25-1000^{\circ} \mathrm{C}$

both from the hydration of calcium silicates in the cement and from the reaction between calcium from the cement and quartz in the silica flour (Bensted, 2008; Nelson and Guillot, 2006). In the control samples and those containing the anionic additives, there was a slight increase in portlandite formation up to $14 \mathrm{~d}$, after which it reduced. This is a different trend to that discerned from XRD analysis, which suggests the formation of both crystalline and X-ray amorphous portlandite (both have been identified in similar grouts (Collier et al., 2015a, 2015b, 2016)). The trend in the formation of portlandite in the grouts containing the cationic additives matched the XRD results, with the quantity decreasing with increasing curing time.

\section{Microstructural/elemental characteristics}

Backscattered electron imaging (BEI) photomicrographs were obtained for all samples and examples for the grouts containing tin chloride are shown in Figure 7. All micrographs showed the presence of solid particles with high atomic mass up to $\sim 50 \mu \mathrm{m}$ in size (likely to be silica flour) embedded in a matrix of a more porous hydration product with lower atomic mass. Qualitatively, there appeared to be very little difference in porosity or microstructural morphology due to the retarders.

EDX analysis showed that calcium $(\mathrm{Ca})$, silicon $(\mathrm{Si})$, oxygen $(\mathrm{O})$ and aluminium $(\mathrm{Al})$ were the main elements present in each sample, with minor amounts of potassium $(\mathrm{K})$, sodium $(\mathrm{Na})$, iron $(\mathrm{Fe})$ and magnesium $(\mathrm{Mg})$. Small peaks for boron (B), 


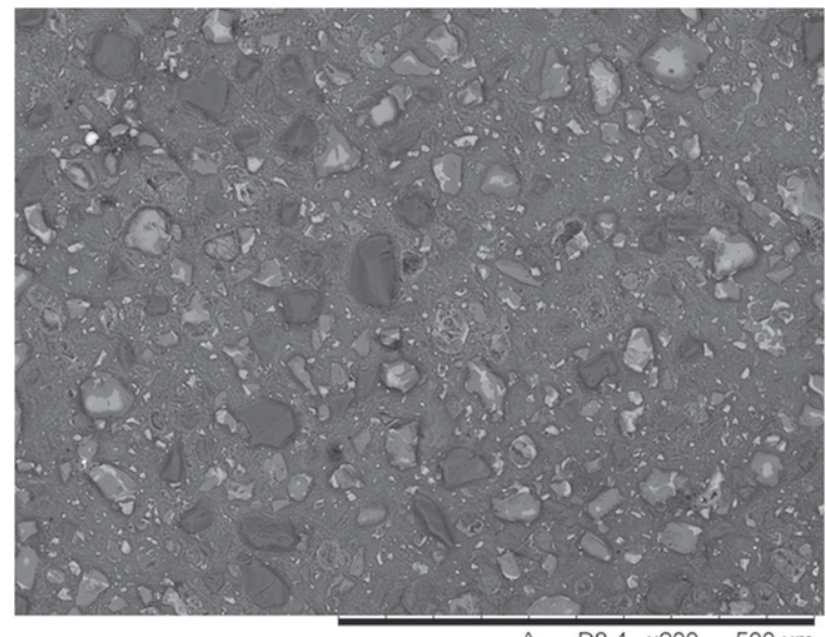

(a)

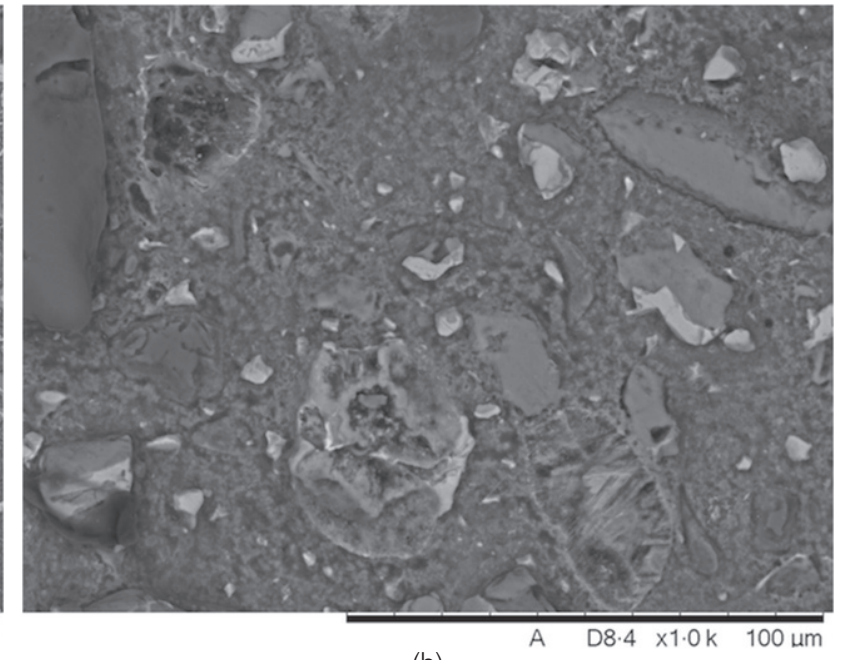

(b)

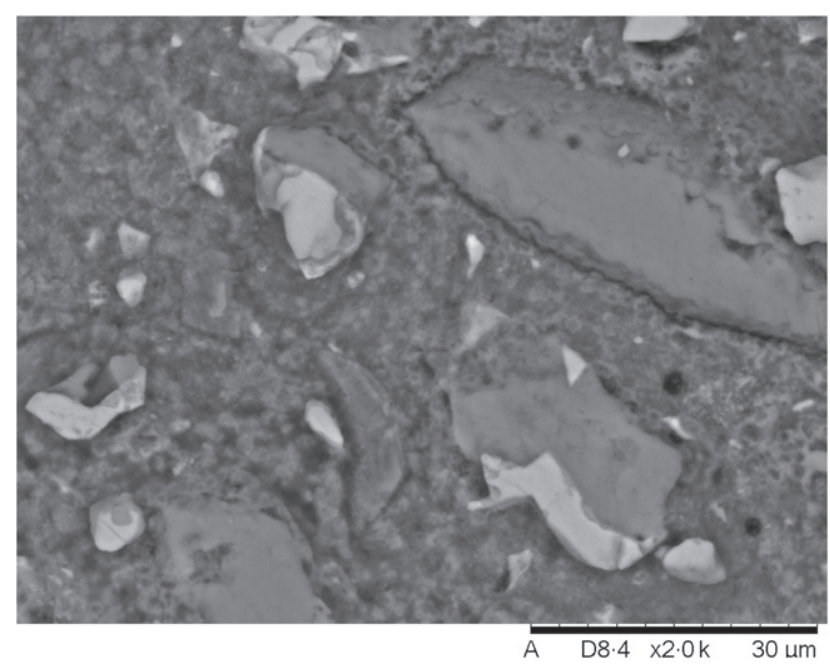

(c)

Figure 7. SEM BEI micrographs of grouts containing $2.0 \%$ tin chloride

phosphorus $(\mathrm{P})$, tin and zinc were detected in each respective sample, although the presence of boron should be treated with caution because it was at the threshold of detection with the equipment used. Elemental EDX maps were obtained for all samples at $\times 2000$ magnification to show the distribution of the main elements; an example is shown in Figure 8 for the zinc nitrate sample. A number of characteristics were common to each sample type. The majority elements were calcium, silicon and oxygen due to the $\mathrm{C}-\mathrm{S}-\mathrm{H}$ phases. Particles rich in silicon and oxygen only (Figures 8(f) and 8(h)) were likely to be silica flour; particles rich in calcium, aluminium and iron (Figures 8(d), 8(e) and 8(g)) were likely to be unhydrated brownmillerite; this indicated that not all of these phases had reacted by $28 \mathrm{~d}$. Some silica particles showed evidence of reactions (darker areas within the particles), likely to be due to reactions with calcium to form $\mathrm{C}-\mathrm{S}-\mathrm{H}$ phases. Areas rich in calcium only were likely to be calcium hydroxide $\left(\mathrm{Ca}(\mathrm{OH})_{2}\right)$.
In each respective sample, boron, phosphorus, tin and zinc were pervasive, and were not coincident with any other element, suggesting no new phase formation. No microstructural characteristics specific to sample type were identified.

\section{Discussion}

Each inorganic compound was found to influence the wet paste properties and retarded grout thickening at 90 and $120^{\circ} \mathrm{C}$ (at $50 \mathrm{MPa}$ ). Of all the materials studied, sodium borate was most effective at delaying the attainment of $70 \mathrm{Bc}$ consistency. At $90^{\circ} \mathrm{C}$, sufficient retardation for DBD was achieved with borate additions of $0 \cdot 75,1.0$ and $2 \cdot 0 \%$, and this was nearly achieved at $120^{\circ} \mathrm{C}$. The tin and zinc compounds were found to have the least influence on consistency. The successfully retarded borate grouts all set within $24 \mathrm{~h}$, meaning that waste package deployment rates of around one per day may be possible. The initial consistency of the borate grout at $90^{\circ} \mathrm{C}$ was 


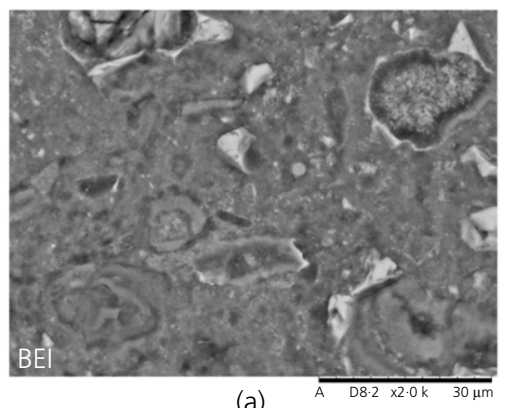

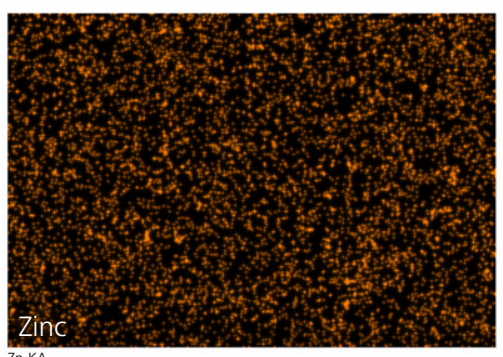

(b)

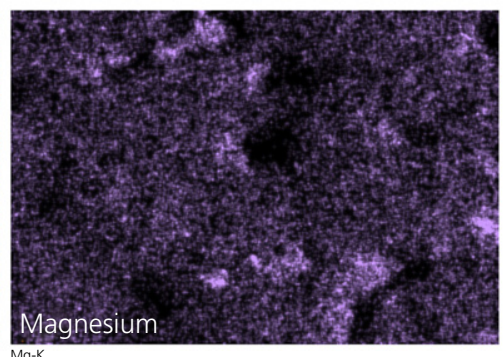

(c)

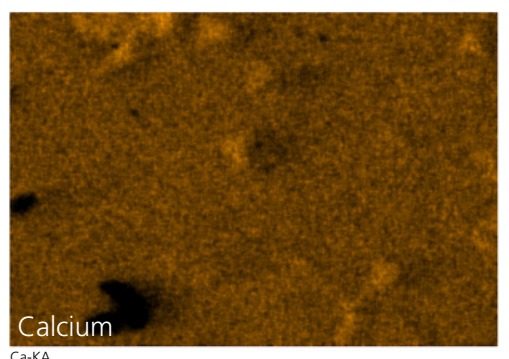

(d)

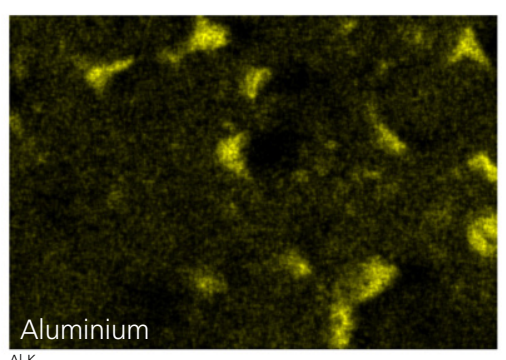

(e)

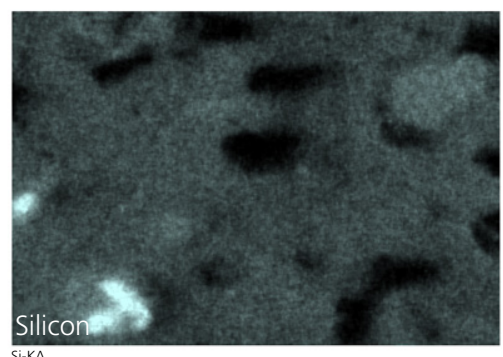

(f)

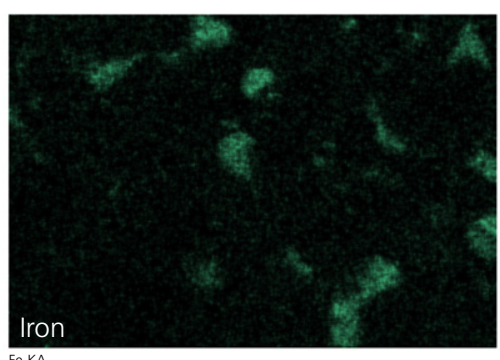

(g)

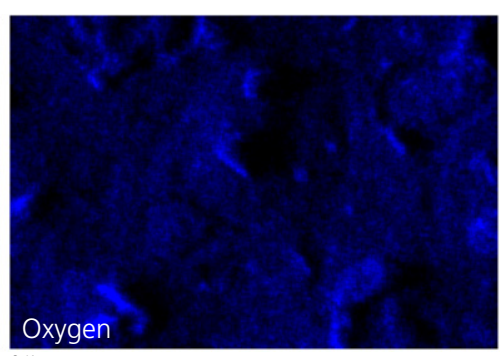

(h)

Figure 8. Elemental EDX maps for the grout made with $2.0 \%$ zinc nitrate

lower than the maximum permissible for pumping, but was exceeded at $120^{\circ} \mathrm{C}$ meaning that it would not be able to be pumped at this temperature. The wet paste rheology study showed that there was an optimum addition level at which the highest plastic viscosity and yield stress was achieved for each grout type. The tin compound appeared to provide plasticising properties, whereas the zinc compound caused grout thickening. Calorimetry revealed that borate had the greatest influence on when cement hydration reactions occurred, corroborating the consistency results (although the difference in testing temperature should be noted). The zinc grouts showed only slight retardation of the hydration reactions. All the results indicate that the influence on wet paste properties is complex and is affected in different ways by different conditions, as reported by other researchers (Shariar, 2011).

None of the retarders affected the phases present in the hardened pastes, which were typical of the class $\mathrm{G}$ cement/silica flour system (Bensted, 2008; Nelson and Guillot, 2006). The general trends in crystalline phase formation were $(a)$ the contents of quartz and portlandite reduced with time due to co-reaction, (b) the tobermorite- $11 \AA$ content increased with 
time and $(c)$ the brownmillerite content changed little with time. $\alpha-\mathrm{C}_{2} \mathrm{SH}$ content reduced with time in the cationic-retarded samples, whereas a corresponding trend in the samples with anionic retarder was unclear. The presence of either borate or phosphate may suppress or hinder the formation of crystalline $\mathrm{C}-\mathrm{S}-\mathrm{H}$ phases. Corroboration of Portlandite content between XRD and TGA/DTG analyses was poor, possibly due to the presence of both crystalline and X-ray amorphous material. Microstructural morphology and elemental distribution in each retarded sample were very similar to those of the control, and particles of unreacted silica flour were embedded within what appeared to be a dense matrix of hydration products. Each retarding ion was pervasive throughout each sample and was not regularly coincident with any other element.

Assessing the applicability of using these inorganic retarders for DBD, only sodium borate can maintain consistency at $<70 \mathrm{Bc}$ for at least $4 \mathrm{~h}$, and then only at $90^{\circ} \mathrm{C}$. At this temperature, the grout should flow around the waste packages and set within the desired time; at $120^{\circ} \mathrm{C}$ there was insufficient retardation. However, temperature is dependent on the hole depth and local geological conditions, so other retarders may be appropriate for use at lower temperatures. In addition, if grout delivery time could be reduced, then sodium borate might be appropriate for use at both temperatures, but its effect on early-age grout consistency may mean that it is too viscous to be pumped. None of the other additives studied provided sufficient retardation at either 90 or $120^{\circ} \mathrm{C}$, so their use in DBD at these temperatures is inappropriate. However, if shallower lower-temperature disposals were to be employed, then their use should be reconsidered.

The durability of DBD grouts is difficult to assess, but the phases present in the hardened grouts are very similar to those in hardened hydrocarbon and geothermal energy well cements, and these have demonstrated durability over $\sim 60$ years. Chemical durability is also important, and the groundwater in hydrocarbon or geothermal energy wells will be more chemically aggressive than in DBD (Milestone et al., 2012; Nelson and Guillot, 2006). Groundwater composition may influence wet paste performance or hardened paste composition; chloride or carbonate phases in the groundwater may influence the hydrate phases formed, which could then influence hardened paste performance and durability.

Cement-based materials may be used in other non-SSM applications in DBD, and elsewhere in hydrocarbon and geothermal energy wells. Other cementing operations in DBD may include securing the casing to the borehole wall rock, providing physical support to targeted downhole areas and final hole sealing above the disposal zone (as in the Sandia reference design for DBD, which uses Portland-cement-based concrete as a component of the main borehole seal (Arnold et al., 2011)). These operations would take place at shallower depths where the temperature and pressure would be lower than in the disposal zone. This will reduce the impact on thickening time and may allow the use of inorganic materials as retarders. Similarly, the depth of hydrocarbon and geothermal energy wells may be less than in $\mathrm{DBD}$, so the impact of temperature and pressure on paste performance may also be reduced, again meaning that inorganic retarders may be appropriate.

\section{Conclusions}

The applicability of using tin, zinc, borate and phosphate compounds as retarders of cement grout thickening for use in DBD has been assessed and the following conclusions were made.

- None of the inorganic compounds assessed are appropriate for use as retarders in DBD at $120^{\circ} \mathrm{C}$ or above.

- Adding sodium borate at $0.75 \%$ by weight of cement provides sufficient retardation for use in DBD at $90^{\circ} \mathrm{C}$. Adding $1 \%$ nearly provides enough retardation at $120^{\circ} \mathrm{C}$.

- Adding sodium phosphate, tin chloride or zinc nitrate in any concentration did not provide sufficient retardation at either 90 or $120^{\circ} \mathrm{C}$.

- It is difficult to identify any distinct trends associated with the influence of any retarder on viscosity or yield stress. However, in all the grouts, as the addition level increased, these parameters increased to a maximum, after which there was a reduction.

- Sodium borate had the greatest influence on the magnitude of heat evolved during cement hydration and provided the longest delay in the times at which heat flow events occurred.

- The phases present in each of the hardened cement pastes were found to be the same as those in class $G$ cement/silica flour well grouts used at temperatures and pressures similar to those required for DBD. None of the inorganic additives had any effect on phase composition, although anionic retarders may suppress the formation of crystalline $\mathrm{C}-\mathrm{S}-\mathrm{H}$ phases.

\section{Acknowledgements}

This work was financially supported by the UK Engineering and Physical Science Research Council (grant number $\mathrm{EP} / \mathrm{K} 039350 / 1)$. The research was performed in part at the Midas Facility at The University of Sheffield, which was established with support from the Department of Energy and Climate Change. Thanks are due to Cebo UK Ltd and Minerals Marketing Ltd for the supply of cement and silica, respectively, and Sika Ltd for the supply of some of the additives.

\section{REFERENCES}

API (American Petroleum Institute) (2010) Spec 10A, Specification for Cements and Materials for Well Cementing, 24th edn. API, Washington, DC, USA.

Arliguie G, Ollivier JP and Grandet J (1982) Etude de l'effet retardateur du zinc sur l'hydratation de la pate de ciment Portland. Cement and Concrete Research 12(1): 79-86 (in French). 
Arnold BW, Brady PV, Bauer SJ et al. (2011) Reference Design and Operations for Deep Borehole Disposal of High-Level Radioactive Waste. Sandia National Laboratories, Albuquerque, NM, USA, SAND2011-6749.

Arnold B, Brady P, Altman S et al. (2013) Deep Borehole Disposal Research: Demonstration Site Selection Guidelines, Borehole Seals Design, and RD\&D Needs. Sandia National Laboratories, Albuquerque, NM, USA, FCRD-USED-2013-000409, SAND2013-9490P.

ASTM (2013) C191-13: Standard test methods for time of setting of hydraulic cement by Vicat needle. ASTM International, West Conshohocken, PA, USA.

ASTM (2016) C150/C150M: Standard specification for Portland cement. ASTM International, West Conshohocken, PA, USA.

Atabek R, Bouniol P, Vitorge P, Le Bescop P and Hoorelbeke JM (1992) Cement use for radioactive waste embedding and disposal purposes. Cement and Concrete Research 22(2-3): 419-429.

Bell IS and Coveney P (1998) Molecular modelling of the mechanism of action of borate retarders on hydrating cements at high temperature. Molecular Simulation 20(6): 331-356.

Bénard P, Garrault S, Nonat A and Cau-Dit-Coumes C (2005) Hydration process and rheological properties of cement pastes modified by orthophosphate addition. Journal of the European Ceramic Society 25(11): 1877-1883.

Bénard P, Garrault S, Nonat A and Cau-Dit-Coumes C (2008) Influence of orthophosphate ions on the dissolution of tricalcium silicate. Cement and Concrete Research 38(10): 1137-1141.

Bensted J (2008) Development with oilwell cements. In Structure and Performance of Cements, 2nd edn (Bensted J and Barnes P (eds)). Spon Press, London, UK, pp. 237-252.

Bensted J, Callaghan IC and Lepre A (1991) Comparative study of the efficiency of various borate compounds as set-retarders of class $\mathrm{G}$ oilwell cement. Cement and Concrete Research 21(4): 663-668.

Best MG (2003) Igneous and Metamorphic Petrology. Blackwell Science, Malden, MA, USA.

Beswick J, Gibb F and Travis K (2014) Deep borehole disposal of nuclear waste: engineering challenges. Proceedings of the Institution of Civil Engineers - Energy 167(2): 47-66, http://dx.doi.org/ 10.1680/ener.13.00016

Bonhoure I, Wieland E, Scheidegger AM, Ochs M and Kunz D (2003) EXAFS study of Sn(IV) immobilization by hardened cement paste and calcium silicate hydrates. Environmental Science and Technology 37(10): 2184-2191.

BSI (2009) BS EN ISO 10426-1:2009: Petroleum and natural gas industries, cements and materials for well cementing, specification. BSI, London, UK.

Cau-dit-Coumes C and Courtois S (2003) Cementation of a low-level radioactive waste of complex chemistry investigation of the combined action of borate, chloride, sulfate and phosphate on cement hydration using response surface methodology. Cement and Concrete Research 33(3): 305-316.

Chapman N and Gibb F (2003) A truly final waste management solution: is very deep borehole disposal a manageable solution for high-level wastes or fissile materials? Radwaste Solutions 10(4): 26-37.

Cocke DL and Mollah MYA (1993) The chemistry and leaching mechanisms of hazardous substances in cementitious solidification/stabilisation systems. In Chemistry and Microstructure of Solidified Wasteforms (Spence RD (ed.)). Lewis Publishers, Boca Raton, FL, USA, pp. 187-242.

Collier NC (2016) Transition and decomposition temperatures of cement phases - a collection of thermal analysis data. Ceramics-Silikáty 60(4): 338-343.

Collier NC, Sharp JH, Milestone NB, Hill J and Godfrey IH (2008) The influence of water removal techniques on the composition and microstructure of hardened cement pastes. Cement and Concrete Research 38(6): 737-744.

Collier NC, Travis KP, Gibb FGF and Milestone NB (2015a) Cementitious grouts for disposal of nuclear wasteforms in deep boreholes. Proceedings of American Nuclear Society International High-Level Radioactive Waste Management, Charleston, SC, USA. American Nuclear Society, La Grange Park, IL, USA, pp. $394-400$.

Collier NC, Travis KP, Gibb FGF and Milestone NB (2015b) Characteristics of cementitious paste for use in deep borehole disposal of spent fuel and high level wasteforms. Scientific Basis for Nuclear Waste Management XXXVIII (Matyáš J, Gin S, Jubin R and Vance E (eds)). Materials Research Society, Warrendale, PA, USA, vol. 1744 , pp. 205-210.

Collier NC, Milestone NB, Travis KP and Gibb FGF (2016) The effect of organic retarders on grout thickening and setting during deep borehole disposal of high-level radioactive waste. Progress in Nuclear Energy 90: 19-26, https://doi.org/10.1016/j.pnucene.2016. 02.021 .

Collier NC, Milestone NB and Travis KP (2017a) Lessons learnt from the development of cementitious grouts for deep borehole disposal applications. Journal of Materials in Civil Engineering 29(10): 04017197.

Collier NC, Balboa HE, Milestone NB and Travis KP (2017b) Inorganic anions as retarders for deep borehole disposal grouts. Advances in Cement Research 29(8): 347-357, http://dx.doi.org/10.1680/ jadcr.16.00183.

Csetenyi LJ and Glasser FP (1995) Borate retardation of cement set and phase relations in the system $\mathrm{Na}_{2} \mathrm{O}-\mathrm{CaO}-\mathrm{B}_{2} \mathrm{O}_{3}-\mathrm{H}_{2} \mathrm{O}$. Advances in Cement Research 7(25): 13-19, http://dx.doi.org/ 10.1680/adcr.1995.7.25.13

Demirbas A and Karslioglu S (1995) The effect of boric acid sludges containing borogypsum on properties of cement. Cement and Concrete Research 25(7): 1381-1384.

Gao Y and Song Z (2013) The influence on cement setting time and compression strength by adding stannous sulphate. Study of Civil Engineering and Architecture 2(4): 85-89.

Gibb FGF (2010a) Deep borehole disposal (DBD) methods and initiatives: a review. Nuclear Engineering International, February: p. 19.

Gibb FGF (2010b) Looking down the bore, radioactive waste management: deep boreholes. Nuclear Engineering International, February: pp. 21-22.

Gibb F, McTaggart N, Travis K, Burley D and Hesketh K (2008) High-density support matrices: key to the deep borehole disposal of spent nuclear fuel. Journal of Nuclear Materials 374(3): 370-377.

Glasser FP (1992) Progress in the immobilization of radioactive wastes in cement. Cement and Concrete Research 22(2-3): 201-216.

Glasser FP (1993) Chemistry of cement solidified waste forms. In Chemistry and Microstructure of Solidified Waste Forms (Spence RD (ed.)). Lewis Publishers, London, UK, pp. 1-40.

Hill J (1999) Incorporation of Inorganic Metal Salts in Composite Cements. PhD thesis, The University of Sheffield, Sheffield, UK.

Hill J and Sharp JH (2003a) The hydration products of Portland cement in the presence of tin(II) chloride. Cement and Concrete Research 33(1): 121-124

Hill J and Sharp JH (2003b) Heat evolution in composite cements with additions of $\mathrm{Sn}(\mathrm{II})$ and $\mathrm{Sn}(\mathrm{IV})$ chlorides. Advances in Cement Research 15(2): 57-66, http://dx.doi.org/10.1680/ adcr.2003.15.2.57.

Hill J and Sharp JH (2005) Encapsulation of Sn(II) and Sn(IV) chlorides in composite cements. Journal of the American Ceramic Society 88(3): $560-565$. 
Ivey DG, Heimann RB, Neuwirth M et al. (1990) Electron microscopy of heavy metal waste in cement matrices. Journal of Materials Science 25(12): 5055-5062.

Jupe A, Wilkinson A, Luke $\mathrm{K}$ and Funkhouser G (2008) Class H cement hydration at $180^{\circ} \mathrm{C}$ and high pressure in the presence of added silica. Cement and Concrete Research 38(5): 660-666.

Lieber W (1974) The influence of phosphates on the hydration of Portland cement. Proceedings of the 6th International Congress on the Chemistry of Cement, Moscow, USSR.

Lothenbach B, Ochs M and Hager D (2000) Thermodynamic data for the solubility of tin(IV) in aqueous cementitious environments. Radiochimica Acta 88(9-11): 521-526.

Ltifi M, Guefrech A and Mounanga P (2011) Effects of sodium tripolyphosphate addition on early-age physico-chemical properties of cement pastes. Procedia Engineering 10: 1457-1462, https://doi.org/10.1016/j.proeng.2011.04.242.

Ma W and Brown PW (1994) Effect of phosphate additions on the hydration of Portland cement. Advances in Cement Research 6(21): 1-12, http://dx.doi.org/10.1680/adcr.1994.6.21.1.

Milestone NB, Bigley CH, Durant AT, Sharp MDW and da Silva JRMC (2012) Chemical reactions in geothermal cements. New Zealand Geothermal Workshop, Auckland, New Zealand, Paper 112.

Nelson E and Guillot D (eds) (2006) Well Cementing, 2nd edn. Elsevier Science, Amsterdam, the Netherlands.

Odler I (2004) Hydration, setting and hardening of Portland cement. In Lea's Chemistry of Cement and Concrete, 4th edn. (Hewlett PC (ed.)). Elsevier Science and Technology, London, UK, pp. 241-297.
Ramachandran VS and Lowery MS (1998) Conduction calorimetric investigation of the effect of retarders on the hydration of Portland cement. Thermochimica Acta 195: 373-387, https://doi.org/ 10.1016/0040-6031(92)80081-7.

Scherer G, Funkhouser G and Peethamparan S (2010) Effect of pressure on early hydration of class $\mathrm{H}$ and white cement. Cement and Concrete Research 40(6): 845-850.

Shariar A (2011) Investigation on Rheology of Oil Well Cement Slurries. $\mathrm{PhD}$ thesis, The University of Western Ontario, London, ON, Canada.

Shariar A and Nehdi M (2014) Rheological properties of oil well cement slurries. Proceedings of the Institution of Civil Engineers Construction Materials 165(1): 25-44, http://dx.doi.org/10.1680/ coma.2012.165.1.25.

Taylor HFW (1997) Cement Chemistry, 2nd edn. Thomas Telford, London, UK.

Thomas NL, Jameson DA and Double DD (1981) The effect of lead nitrate on the early hydration of Portland cement. Cement and Concrete Research 11(1): 143-153.

Wilding CR, Walter A and Double D (1984) A classification of inorganic and organic admixtures by conduction calorimetry. Cement and Concrete Research 14(2): 185-194.

Young JF (1972) A review of the mechanisms of set-retardation in Portland cement pastes containing organic admixtures. Cement and Concrete Research 2(4): 415-433.

Zhang J, Weissinger E, Peethamparan S and Scherer G (2010) Early hydration and setting of oil well cement. Cement and Concrete Research 40(7): 1023-1033.

\section{How can you contribute?}

To discuss this paper, please submit up to 500 words to the editor at journals@ice.org.uk. Your contribution will be forwarded to the author(s) for a reply and, if considered appropriate by the editorial board, it will be published as a discussion in a future issue of the journal. 